\title{
Инновационные разработки НВП «БашИнком» для защиты и питания растений
}

\author{
() В.С. Сергеев, Л.Ф. Миннебаев, Д.В. Гарифуллина
}

Общество с ограниченной ответственностью «Научно-внедренческое предприятие "БашИнком»

450015, г. Уфра, улица Карла Маркса, 37.

Email:sergeev-vs@mail.ru

Представлены сведения об инновационных разработках НВП «БашИнком» для защиты и питания растений. Разработанные микробные препараты обеспечивают защиту растений от болезней и вредителей, повышают устойчивость растений к стресс-факторам внешней среды, позволяют улучшить минеральное питание, сохранить почвенное биоразнообразие, получать экологически чистую сельскохозяйственную продукцию.

Ключевые слова: биопрепараты и биоактивированные удобрения, полезные бактерии и грибы, эфффективность.

Снизить пестицидную нагрузку на почву, растения, получить экологически чистую продукцию, при этом обеспечить рост урожайности сельскохозяйственных культур при снижении затрат - кредо НВП «БашИнком». Главными достоинствами биопрепаратов и биоактивированных удобрений, выпускаемых предприятием, являются их высокая эфрфективность, качество и безопасность для человека и животных. Высокий уровень разработок коллектива компании отмечен многочисленными наградами - 60 золотыми медалями, 200 дипломами и грамотами, полученными на российских и международных выставках.

НВП «БашИнком» отличается тем, что здесь разрабатываются, испытываются и регистрируются производимые биопрепараты и биоактивированные удобрения. Мощная научно-исследовательская база предприятия и тесное сотрудничество со многими НИИ и университетами позволяет проводить разработку новых, более эфффективных препаратов и на их базе разрабатывать и внедрять современные биологизированные технологии возделывания сельскохозяйственных культур.

Особое место в линейке инновационных разработок занимают микробиологические препараты серии Фитоспорин. Суперновинка компании - это биофунгицид Фитоспорин-М, Ж (АС), который включает 3 основных вида полезных микроорганизмов - антагонистов фитопатогенов: Bacillus subtilis (сенная палочка), Trichoderma reesei и лизаты (метаболиты) бактерий рода Pseudomonas: aureofaciens и fluorescens. Еще одна сильная сторона биопрепарата Фитоспорин-M, Ж (AC) - входящий в его состав L- $\alpha-$ аминокислоты (аспарагиновая кислота, глицин, лизин и т. д.). Биопрепарат эфффективно защищает растения от корневых гнилей, мучнистой росы, альтернариоза, фритофтороза, парши, ржавчины и других опасных заболеваний. Препарат начинает работать сразу после внесения и действует значительно дольше, чем химический фунгицид. В отличие от «химии», не вызывает формирования резистентности у фитопатогенов. Отличается высокой эфффективностью даже в условиях низкой положительной температуры окружающей среды - от +4 градусов. Обладает высокой фрунгицидной и бактери- 
цидной активностью в сочетании с антистрессовыми, ростоускоряющими и иммуностимулирующими свойствами.

Еще одна разработка - новое микробиологическое органогуминовое удобрение Хозяин Плодородия с Кормилицей Микоризой. В состав нового препарата добавлена микориза, что многократно увеличивает возможности растения по улучшению питания, пищевого режима, влагозапасам и влагосбережению. Его можно без проблем вносить во время сева с помощью сеялок как припосевное удобрение, благодаря форме выпуска в виде гранул. Микориза, которая содержится в удобрении, способствует мощному развитию корневой системы, улучшает пищевой режим почвы и водообеспеченность растений.

БиоАзФК - микробиологическое удобрение для улучшения азотного, фосфорного и калийного питания с антистрессовыми, ростоускоряющими, иммуностимулирующими свойствами. В состав препарата входит целый консорциум живых микроорганизмов: азотфиксирующие бактерии Azotobacter chroococcum, фоссрормобилизующие бактерии Bacillus megaterium, фосфрор- и калиймобилизующие бактерии Bacillus mucilaginosus, природные полисахариды, фитогормоны, витамины. Применение этого удобрения способствует укреплению иммунитета и повышению стрессоустойчивости растений, повышению урожайности и получению экологически чистой продукции, а также оздоровлению почвы в целом.

Микробиологический препарат для оздоровления почвы и разложения растительных остатков СТЕРНЯ-12, который содержит четыре штамма спорообразующих бактерий Bacillus subtilis, три вида гриба Trichoderma, комплекс целлюлозолитических фрерментов, а также природные полисахариды, фитогормоны и витамины. Препарат не только способствует оздоровлению почвы, но и обеззараживает пожнивные остатки зерновых, подсолнечника, кукурузы и других культур, оставшихся на полях после уборки. Кроме того, СТЕРНЯ-12 улучшает пищевой режим почвы, нейтрализует остатки химических пестицидов.

Разработан новый биологический прилипатель «Биолипостим», который по соотношению цена - качество превосходит отечественные и импортные химические прилипатели. В составе препарата - полисахариды растительного и микробиологического происхождения, которые растение воспринимает как свои. Препарат применяется для повышения эффрективности средств защиты растений, регуляторов роста и водорастворимых удобрений при предпосевной обработке и в период вегетации сельхозкультур. Биолипостим совместим со всеми пестицидами, жидкими и водорастворимыми удобрениями, содержащими макро-, мезо- и микроэлементы в хелатной форме.

В числе других разработок «БашИнкома» следует отметить инокулянты серии РизоБаш. Препарат обладает высокой концентрацией азотфиксирующих клубеньковых бактерий, улучшает азотный режим почвы, снижает дозы внесения азотных удобрений, повышает урожайность и содержание протеина в урожае бобовых культур.

Завершается работа по регистрации биоинсектицидов ТуринБаш и Боверикс. В состав первого инсектицида входят штаммы бактерий Bacillus thuringiensis. Препарат применяется для борьбы с вредителями сельскохозяйственных культур: колорадским жуком (личинки 1-2-го возрастов), капустной молью, репной и капустной белянкой, огневкой (гусеницы 1-2-го возрастов), плодовой и яблонной молью (гусеницы 1-2-го возрастов) и др. Второй биоинсектицид на основе энтомопатогенного гриба Beauveria bassiana, который поражает широкий круг чешуекрылых, жесткокрылых, полужесткокрылых, прямокрылых и перепончатокрылых насекомых, а также некоторые виды клещей. 
Внедрение в производство новых микробиологических разработок позволит стабилизировать агроценозы, повысить плодородие почвы и расширить возможности производства экологически чистых продуктов питания. Необходимость применения биопрепаратов понимают многие сельхозпроизводители, хотя перелома в понимании экологических проблем пока не наступило. Поэтому мы видим хорошие перспективы использования биопродукции в растениеводстве, которые, безусловно, будут расширяться вместе с ростом уровня сельскохозяйственного производства. 